\title{
HVMANITAS
}

\section{[Recensão a] Código pedagógico dos jesuítas: ratio studiorum da Companhia de Jesus [1599]: regime escolar e curriculum de estudos}

Autor(es): $\quad$ Andrade, António Publicado por: $\begin{aligned} & \text { Faculdade de Letras da Universidade de Coimbra, Instituto de Estudos } \\ & \text { Clássicos }\end{aligned}$

URL persistente:

URI:http://hdl.handle.net/10316.2/23251

DOI: $\quad$ DOI:http://dx.doi.org/10.14195/2183-1718_62_23

Accessed : $\quad$ 26-Apr-2023 15:34:39

A navegação consulta e descarregamento dos títulos inseridos nas Bibliotecas Digitais UC Digitalis, UC Pombalina e UC Impactum, pressupõem a aceitação plena e sem reservas dos Termos e Condições de Uso destas Bibliotecas Digitais, disponíveis em https://digitalis.uc.pt/pt-pt/termos.

Conforme exposto nos referidos Termos e Condições de Uso, o descarregamento de títulos de acesso restrito requer uma licença válida de autorização devendo o utilizador aceder ao(s) documento(s) a partir de um endereço de IP da instituição detentora da supramencionada licença.

Ao utilizador é apenas permitido o descarregamento para uso pessoal, pelo que o emprego do(s) título(s) descarregado(s) para outro fim, designadamente comercial, carece de autorização do respetivo autor ou editor da obra.

Na medida em que todas as obras da UC Digitalis se encontram protegidas pelo Código do Direito de Autor e Direitos Conexos e demais legislação aplicável, toda a cópia, parcial ou total, deste documento, nos casos em que é legalmente admitida, deverá conter ou fazer-se acompanhar por este aviso. 
humanitas

Vol. LXII

2010 
Código Pedagógico dos Jesuítas. Ratio Studiorum da Companhia de Jesus [1599]. Regime Escolar e Curriculum de Estudos. Prefácio de Pe. Luiz Fernando Klein, S.J.; nota prévia, introdução, versão portuguesa e notas de Margarida Miranda; Ratio Studiorum: um modelo pedagógico de José Manuel Martins Lopes, S.J.; posfácio de Norberto Dallabrida. Lisboa, Esfera do Caos Editores, 2009, 290 pp. ISBN 978-989-8025-89-0

A obra em epígrafe constitui um texto matricial da acção pedagógica instituída pelos Jesuítas a partir da rede alargada de Colégios da Companhia de Jesus que, não obstante ter tido a sua origem no continente europeu, atingiu em poucas décadas uma escala verdadeiramente global, estendendo-se à América, Ásia e África. A Ratio Studiorum dos Jesuítas, cuja publicação em letra de forma data de 1599, representa o coração de um modelo pedagógico de enorme sucesso, cujas raízes mais profundas assentam no Humanismo.

Esta obra conta com um prefácio de Pe. Luiz Fernando Klein, S.J. (pp. 15-16) e um posfácio da autoria de Norberto Dallabrida, sob o título «A Ratio Studiorum e a Modernidade Pedagógica no Mundo Católico» (pp. 287-290). Além disso, convém sublinhar a publicação de dois estudos introdutórios de inegável qualidade que proporcionam ao leitor deste livro uma visão esclarecida e actualizada sobre a Ratio Studiorum da Companhia de Jesus. Em primeiro lugar, da autoria de Margarida Miranda, encontramos o estudo intitulado «Ratio Studiorum: uma Nova Hierarquia de Saberes» (pp. 17-36), ao qual se segue, da autoria de José Manuel Martins Lopes, S.J., um outro trabalho subordinado ao título «Ratio Studiorum: Um Modelo Pedagógico» (pp. 37-51). A leitura de ambos os estudos revela-se fundamental para uma compreensão das inúmeras questões suscitadas pelo texto que definia o regime escolar e o curriculum de estudos dos Colégios da Companhia de Jesus, seja na definição e compreensão do contexto que está na génese desta obra, seja na reflexão esclarecida sobre o que realmente significou, no passado, a Ratio Studiorum dos Jesuítas, sem descurar, evidentemente, o contributo valioso que, no presente, a sua leitura pode continuar a dar a múltiplas áreas de saber.

A parte central do volume contém a edição moderna da Ratio Studiorum (com base na edição crítica de Ladilaus Lukács, S.J.), acompanhada de uma excelente versão portuguesa a cargo de Margarida Miranda. O cotejo entre o original latino e a versão portuguesa da Ratio Studiorum encontra-se bastante facilitado pela apresentação, lado a lado, de ambos os textos. Deve notar-se, também, a existência de inúmeras notas à tradução que se revelam 
bastante proveitosas, porquanto ajudam o leitor a superar as dificuldades naturais de interpretação e contextualização de uma obra que nos remete para um tempo, uma prática e uma realidade muito distinta daquela que prevalece nos nossos dias. Merece, ainda, uma referência positiva, pela sua enorme utilidade, a completa e actualizada bibliografia disponível na parte final do livro (pp. 269-285).

É, pois, com bastante agrado que saudamos a publicação do Código Pedagógico dos Jesuítas, uma obra que representa um modelo de formação integral, no qual foram formadas, ao longo de vários séculos, sucessivas gerações de indivíduos, tanto leigos como religiosos, a quem devemos a transmissão de um valioso legado cultural e civilizacional.

ANTÓNIO ANDRADE

DE BERTI, Raffaele, GAGETTI, Elisabetta e SLAVAZZI, Fabrizio (coords.), Fellini-Satyricon: l'imaginario dell'antico. Cisalpino, Istituto Editorial Universitario - Monduzzi Editoriale, S.r.l., 2009, 585 pp. ISBN 97888-6521-017-8

O diálogo entre as letras clássicas e a literatura e cultura contemporâneas tem sido objecto, nos últimos anos, de múltiplos debates, aturadas reflexões, repetidos estudos e, não raro, acesa controvérsia. Trata-se, sem dúvida, de assunto de justificada complexidade, onde não é fácil encontrar unanimidade nem coincidência de pontos de vista e de metodologias. Se, por um lado, continua a haver quem prefira utilizar como perspectiva a "crítica de fontes", na busca de similitude de passos, de expressões, de fragmentos, não falta, por outro lado, quem se limite à busca de influências, entendidas estas de uma forma genérica, sem um nível de concretização que a crítica de fontes, por via de regra, requer. Em um e outro caso, parece insistente a procura de resposta a perguntas do tipo teria $\mathrm{X}$ lido $\mathrm{Y}$ ? A ambas as opções parece contrapor-se, desde que a estética da recepção apontou novas matrizes de análise, uma outra: temas e expressões das literaturas clássicas fazem parte, por assim dizer, da cultura que herdámos, que nos chegou com o correr dos séculos, filtrada por um sem-número de leituras, de estudos, de obras, onde se vão replicando sucessivamente, até se lhes perder a origem e, portanto, a dimensão autoral e a identidade primeira. Mas nem por isso essa origem deixa de existir e, portanto, de justificar estudo e atenção. Aquela que pode 